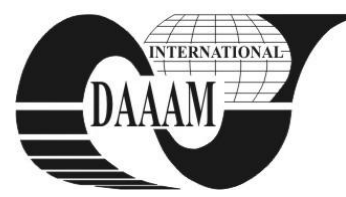

\title{
ANALYSIS OF THE VOLUNTARY DISCLOSURE OF COMPANIES' PERFORMANCE INDICATORS
}

\author{
NISTOR, N[icoleta]; PREDESCU, L[orena] \& ISTUDOR, I[leana] I[ulia]
}

\begin{abstract}
This study presents results of a research on voluntary disclosure of performance indicators by listed companies in Romania. The analysis of financial statements according IFRS was conducted for the period 2006-2010, whereas for those made under the RAS, the analysis period was set to 2005-2010. The main objective was to develop an instrument to measure the degree of transparency on financial ratios published by listed companies. Finally, conclusions were drawn and possible future research directions.
\end{abstract}

Key words: voluntary disclosure, financial ratios, financial statements

\section{INTRODUCTION}

Based on the results of studies conducted so far, this study aims to determine the degree of transparency of listed companies in terms of voluntary disclosure of financial indicators of performance, retaining as the variables crucial to Romania, the company size measured by market capitalization and the listing category.

To measure the degree of transparency, we started on this process from the content analysis of annual reports published on own website, on a 5-years reference period (2006-2010) for the reports drawn according IFRS and 6 years (2005-2010) for those made according RAS. At the same time, we followed the section in which this information was disclosed (shareholders/investors, annual report, National Securities Company(CNVM) report). Finally, the analysis was extended to follow up disclosure of six categories of financial indicators, developing a composite index score which measures the degree of transparency on the disclosure of financial ratios.

\section{METHODOLOGY}

The research methodology consisted joining of theoretical research on voluntary disclosure practices of information on the Internet (empirical studies conducted on national and international level) with empirical research, by applying research methods: observation of dynamic documentary content of web financial-research reports and analyzing the information revealed from published financial reports of listed companies with diagnostic methods, case study, accounting investigations.

Conclusions, proposals and future directions of research were presented at the end of the study.

\section{THE STAGE OF RESEARCH ON PRACTICES OF VOLUNTARY PUBLICATION OF INFORMATION ON THE INTERNET}

The literature distinguishes between mandatory and voluntary disclosure of financial and accounting information by companies. The voluntary disclosure of information is placed in the context of agency theory in order to reduce the information asymmetry between principals and agents.
Regarding the disclosure of financial indicators of performance in annual reports, studies undertaken so far are almost absent. Watson et.al. (2002) conducted a study (on 313 companies) about reporting practices via the Internet of information on listed companies' financial indicators.

The studies on voluntary disclosure of information on own website in Romania are still few in number. Studies such as Tiron Tudor A.\& Cristea S. (2006), Ionascu M. et al. (2008), Popa (2008), Popa et al. (2008) reveals a low level of voluntary communication practices. Tiron Tudor et al. (2006) studied the transparency of romanian listed companies on Internet financial reporting practices and disclosure of financial and non-financial information. Popa (2008) conducted a study on online financial reporting practices by listed companies and showed that they are influenced by company size and listing category. Popa et al. (2008) conducted a similar study on listed companies, by searching also the influence of ownership structure. The results obtained showed that the high share of foreign capital is an important determinant factor of Internet financial reporting. Ionascu et al. (2008) are interested in the quality of published information, the disclosure practices and the cost of capital, assessing the impact of the IAS/IFRS regulations on the cost of capital.

From research presented, it is found that too little has focused on studying the reporting practices of financial indicators in annual reports of listed companies presented on own website. This study focuses on this aspect.

\section{DATA COLLECTION AND THE RESEARCH MODEL}

All information necessary for this research were obtained from the following sources: www.bvb.ro, websites of listed companies in the sample.

The website has been retained as a basic material in this research because it has become one of the main vectors of financial communication. This study focuses on companies listed on Bucharest Stock Exchange, from which we selected the companies listed at categories I, II and III. From the sample were removed the financial companies and those which were tagged "unlisted". Therefore, the sample included 64 companies.

We used the model of Meek, Roberts and Gray (1995) and grouped the financial indicators into categories: rates of return (8), structure of asset rates (6), structure of liabilities rates (5), liquidity / solvency ratios(2), value creation (2) and stock market ratios(3).

To measure the degree of transparency on financial indicators, we constructed a composite index, using the Cooke model (1989). For each company in the studied sample it was assigned the value 1 to the categories of indicators disclosed by the company on own website, and 0 - otherwise. Thus, we determined the score for each company by summing assigned values, for the entire analyzed period, both on the basis of RAS and IFRS. 
Index of reporting the financial indicators used to quantitatively measure the level of transparency is determined by the formula:

$$
\operatorname{ScorIND}=\sum_{k=0}^{6} I N D_{k}
$$

The correlation between the company size, measured by market capitalization and the degree of transparency, measured by ScoreIND, is presented in the following table:

\begin{tabular}{|c|c|c|c|c|c|}
\hline $\begin{array}{c}\text { No } \\
\text { comp. }\end{array}$ & $\begin{array}{c}\text { ScoreIND } \\
\text { RAS }\end{array}$ & $\%$ & $\begin{array}{c}\text { No } \\
\text { comp. }\end{array}$ & $\begin{array}{c}\text { ScoreIND } \\
\text { IFRS }\end{array}$ & $\%$ \\
\hline 13 & 5 & $76 \%$ & 1 & 5 & $6 \%$ \\
\hline 3 & 4 & $18 \%$ & 1 & 2 & $6 \%$ \\
\hline 1 & 3 & $6 \%$ & 15 & 0 & $88 \%$ \\
\hline 17 & & $100 \%$ & 17 & & $100 \%$ \\
\hline
\end{tabular}

Tab. 1. The degree of transparency and market capitalization

\section{INTERPRETATION OF RESULTS}

Calculated ScoreIND points out that, for now, companies in Romania publish more information about the financial indicators in the financial statements prepared in accordance with RAS, than in the reports prepared under IFRS. Also, research shows that $23 \%$ of companies listed on BSE belong to category I and they publish the financial indicators under RAS in $87 \%$, while the companies listed in category II and III represent $77 \%$ of total and are more reserved about the disclosure of financial indicators (only 56\%).

The study on the degree of financial indicators disclosure shows that the company size measured by market capitalization is an important determinant factor for publishing such information, confirming thus, the hypothesis from which we started. Thus, $26 \%$ of the companies in the sample total $94.73 \%$ of market capitalization in the studied market. Of these, $76 \%$ public $83 \%$ of the categories of analyzed indicators, according to RAS, and only $6 \%$ of these public the same types of indicators according IFRS.

The research results show that no company publishes information on the value creation indicators.

Regarding the section of website in which are presented the financial indicators, the research has shown the preference of companies for the section dedicated to investors.

\section{CONCLUSION}

First, in the analyzed period, 2005-2010, the low degree of transparency of listed companies in Romania on the publication on own website of the financial ratios under IFRS is due to the fact that there were not prepared financial statements under IFRS, and also to not publishing of these indicators in annual reports under IFRS.

Second, the publication of financial indicators in annual reports according RAS is due in large measure, to the obligation to present in the set frame of financial statements of some performance indicators. This leads to the conclusion that also here, the voluntary disclosure of information would be substantially reduced.

Third, we observed the correlation between the information published, listing category and company size: category I includes large companies in terms of market capitalization, more active and more visible on the market, reason for what they have a much higher degree of transparency.

A future research approach could be extending the study on each sub-category of performance indicators for a better understanding of factors influencing their voluntary disclosure, following possible correlations with corporate governance policy and its main axes (e.g. ownership structure) . Research concerning the organizational memory in the accounting and financial (AF) area (Anica-Popa, 2010) and ontologies implemented in the particular field of international standards (Teller, 2008) revealed modern instruments for the capitalization of knowledge which AF professionals could use in their daily activities, including for underpinning the performance indicators and the reporting policies. For analysing past experiences and for outline some future economic and legislation trends in $\mathrm{AF}$ reporting, we could try to leverage these kind of organizational resources, depending on their availability and accessibility degrees.

\section{ACKNOWLEDGEMENTS}

This study was conducted in the frame of doctoral research project underway, financed by European Social Fund through Sectoral Operational Programme for Human Resources Development 2007 - 2013, in the key area of intervention 1.5. "Doctoral and postdoctoral programs in support of research". The project title is "Doctoral Scholarships, the premise for increasing the competitiveness and competence in scientific research" Project ID 63269.

\section{REFERENCES}

Anica-Popa, L.-E. (2010), Capitalizing the cognitive acquis in the accounting and financial area. A morphology of the organizational memory, Annals of DAAAM for 2010 \& Proceedings of the 21st International DAAAM Symposium, pg. 0734, ISSN 1726-9679

Cooke T.E. (1989) - Disclosure in the corporate annual reports of Swedish companies, Accounting and Business Research, 19 (74), p. 113-124

Ionascu M., Mihai S., Ionascu I.(2008) - Disclosure quality, disclosure regulations and the cost of capital, Journal of Accounting and Management Information Systems, 24,p. 722

Meek G.K., Roberts C.B., Gray S.J.(1995) - Factors influencing voluntary annual report disclosures by US, UK and continental European multinational corporations, Journal of International Business Studies, 26(3),p. 555-572

Popa, A. (2008) - Online Financial Reporting: an empirical study of companies listed on BSE" în: Quality management of accounting information, Georgescu I., Tugui A., Al.I.Cuza University Publishing, Iaşi,p.239-247

Popa A., Farcane N., Blidisel R. (2008) - Internet business reporting a challenge: the case of Romanian manufacturing enterprises, in Proceedings of International Symposium „Intelligent Manufacturing \& Automation: Focus on Next Generation of Intelligent Systems and Solutions", Trnava, Slovakia,p.1101-1102

Teller, P. (2008), A Model for Accounting Standards and its Applications, in: Proceedings of the 17th International Conference on Software Engineering and Data Engineering (SEDE-2008), June 30 - July 2, Los Angeles, California, USA, p. 289-300

Tiron Tudor A., Cristea S.,(2006) - Disclosure and Transparency-Principle of Corporate Governance Romanian Case Study, 3th International Conference - An Entreprise Odyssey: Integration or Disintegration, Lovorka Galetic Zagreb, Croatia Editor: Faculty of Economics and Business, Mikrorad, Zagreb,p. 467-476

Watson A., Shrives P., Marston C. (2002) - Voluntary Disclosure of Accounting Ratios in the UK., British Accounting Review, 34, 4, p. 289-313

Thietart R.A. et coll.(2010) - Méthodes de recherche en management, $3^{\mathrm{e}}$ édition, Pearson Education, Paris 